\title{
A comparative expression analysis of gene transcripts in brain tissue of non-transgenic and GH-transgenic zebrafish (Danio rerio) using a DDRT-PCR approach
}

\author{
FERNANDA A. ALVES-COSTA ${ }^{1}$, MÁRCIO A. FIGUEIREDO ${ }^{2}$, CARLOS F.C. LANES ${ }^{2}$, \\ DANIELA V. ALMEIDA ${ }^{2}$, LUIS F. MARINS ${ }^{2 *}$ and ADRIANE P. WASKO ${ }^{1 *}$ \\ ${ }^{1}$ Departamento de Genética, Instituto de Biociências, UNESP, \\ Distrito de Rubião Jr, s/n, 18618-970 Botucatu, SP, Brasil \\ ${ }^{2}$ Instituto de Ciências Biológicas, Universidade Federal do Rio Grande (FURG), \\ Av. Itália, km 8, 96201-900 Rio Grande, RS, Brasil
}

Manuscript received on May 23, 2011; accepted for publication on July 18, 2011

\begin{abstract}
The presence of higher level of exogenous growth hormone (GH) in transgenic animals could lead to several physiological alterations. A GH transgenic zebrafish (Danio rerio) line was compared to nontransgenic (NT) samples of the species through a DDRT-PCR approach, with the goal of identifying candidate differentially expressed transcripts in brain tissues that could be involved in GH overexpression. Densitometric analyses of two selected amplification products, $p 300$ and $A D C Y 2$, pointed to a significant lower gene expression in the transgenic zebrafish $(104.02 \pm 57.71 ; 224.10 \pm 91.73)$ when compared to NT samples $(249.75 \pm 30.08 ; 342.95 \pm 65.19)$. The present data indicate that $\mathrm{p} 300$ and ADCY2 are involved in a regulation system for GH when high circulating levels of this hormone are found in zebrafishes.
\end{abstract}

Key words: differential display, GH, growth hormone, transgenic, zebrafish.

\section{INTRODUCTION}

The growth hormone gene $(\mathrm{GH})$ is primarily responsible for the regulation of processes related to somatic growth in animals. However, GH may also affect the metabolism of fats, proteins and carbohydrates, the maintenance of the immune system and stress response, regulating the expression of a number of genes involved in

*These authors contributed equally to this work Correspondence to: Fernanda Antunes Alves-Costa E-mail: fa_alves2003@yahoo.com.br these processes. However, there is few data on the GH effects in brain. In this study, brain tissue from a transgenic line of Danio rerio (strain F0104) to the growth hormone gene (GH) were used for the identification and characterization of DETs (Differential Expressed Transcripts), through comparisons with brain tissue from a nontransgenic strain of this species. This study opens up important perspectives for the elucidation of mechanisms used by GH to control the expression of genes related to brain functions. 


\section{RESULTS}

The growth hormone $(\mathrm{GH})$ is a multiple-function hormone whose excess can cause several physiological and behavioral collateral effects in the organism (Bartke et al. 1998, Cook et al. 2000, Brown-Borg et al. 2001, Rosa et al. 2008). Therefore, the presence of a higher level of exogenous GH in transgenic animals could lead to metabolic alterations that can influence not only the animal growth, but also several other traits.

During the last decade, the interest on GH overexpression effects has increased significantly, and several transgenic animal models overexpressing $\mathrm{GH}$ have been developed, including mammals (mouse and rat) and some teleost fishes (Oncorhynchus mykiss, Danio rerio) (Ikeda et al. 1998, Devlin et al. 2001, Lall et al. 2004, Figueiredo et al. 2007). However, there is few data on the GH overexpression effects in brain, a feature that has only been clearly analyzed using mouse GH transgenic models (Lall et al. 2004, Bohlooly-Y et al. 2005). As the GH secretion in the brain is regulated through a complex neuroendocrine control system that is modulated by hypothalamic peptides and neurotransmitter networks (Müller et al. 1991), it would be interesting to determine which genes in this tissue could be associated with GH overexpression.

GH transgenic zebrafish (Danio rerio) represents one of the most explored species lines with an exogenous gene. However, the effects of growth hormone overexpression in the brain of this transgenic animal were not clarified so far. Therefore, the present study intended to identify candidate DETs (Differentially Expressed Transcripts) in brain samples of GH transgenic and non-transgenic zebrafishes using a DDRT-PCR (Differential Display Reverse Transcription - Polymerase Chain Reaction) approach due to its fast, reproducible and technically easier methodology. Moreover, DDRT can detect low abundance mRNA species (Liang 2002, Pardee and McClelland 1999).
Six adult zebrafishes - three non-transgenic (NT) and three GH transgenic - were obtained from Universidade Federal do Rio Grande (Rio Grande, RS, Brazil). The GH transgenic zebrafish belong to the F0104 line that has a carp (Cyprinus carpio) $\beta$-actin promoter driving the expression of two exogenous genes - the growth hormone gene from the marine silverside fish (msGH) Odonthestes argentinensis and the jellyfish (Aequorea victoria) GFP (Green Fluorescent Protein) as a reporter gene to monitor for transformed zygotes (Figueiredo et al. 2007). Transgenic and NT genotypes were determined through UV fluorescence analysis with an epifluorescence microscope (excitation $=485$ $\mathrm{nm}$; emission $=520 \mathrm{~nm}$ ) through the presence or absence of a fluorescence level related to the GFP expression. All procedures were carried out according to the international practices for animal use and care under the control of an internal committee of the Universidade Federal do Rio Grande (FURG), Rio Grande, RS, Brazil.

Brain samples were collected from the animals and $100 \mathrm{mg}$ of each tissue were mechanically homogenized with $1 \mathrm{~mL}$ of TRizol Reagent (Invitrogen Life Technologies), following the manufacturer's instructions. Total RNA samples were incubated with DNase I and eluted in RNasefree water. The samples were quantified (Thermo Scientific NanoDrop 1000 Spectrophotometer) by measuring the optical density (OD) at 260nm. RNA purity was ensured by obtaining a $260 / 280 \mathrm{~nm}$ OD ratio $\geq 1.80$. Approximately $5 \mu \mathrm{g}$ of RNA samples were reverse transcribed (RT-PCR) with the commercial kit SuperScript III RT (Invitrogen Life Technologies) using the oligonucleotide AP (5'-GG CCACGCGTCGACTAGTAC(T) $\left.17^{-3} 3^{\prime}\right)$ according to the manufacturer's instructions.

Each cDNA amplification reaction consisted of $1 \mu \mathrm{L}$ of cDNA, $0.2 \mathrm{mM}$ of primer (designed based on VNTR - Variable Number of Tandem Repeats - core sequences) (Table I), 1x 25mM $\mathrm{MgCl}_{2}$ PCR buffer, $0.2 \mathrm{mM}$ of dNTPs, and 0.2 unit 
TABLE I

Oligonucleotides that were designed based on VNTR core sequences and used as single primers for the amplification of the cDNA samples of Danio rerio.

\begin{tabular}{ccc}
\hline Primer & Sequence (5' - 3') & Reference \\
\hline INS & ACAGGGGTGTGGGG & Nakamura et al. (1987) \\
YNZ22 & CTCTGGGTGTCGTGC & Nakamura et al. (1987) \\
HBV5 & GGTGTAGAGAGGGGT & Nakamura et al. (1987) \\
HBV3 & GGTGAAGCACAGGTG & Nakamura et al. (1987) \\
FvIIex8 & ATGCACACACACAGG & Murray et al. (1988) \\
EMBL & AGAGCTTCAGGCTGGGCAGCTAAG & Harris and Wright (1995) \\
\hline
\end{tabular}

of Platinum Taq DNA polymerase (Invitrogen Life Technologies) in a final volume of $25 \mu \mathrm{L}$. Reactions were carried out with an initial denaturation step at $95^{\circ} \mathrm{C}$ for 2 minutes, followed by 40 cycles at $94^{\circ} \mathrm{C}$ for 50 seconds, $55^{\circ} \mathrm{C}$ for 2 minutes, and $72^{\circ} \mathrm{C}$ for 50 seconds, with an additional extension step at $72^{\circ} \mathrm{C}$ for 5 minutes. Amplification products $(10 \mu \mathrm{L})$ were fractionated on $6 \%$ polyacrylamide gel, stained with $0.17 \%$ silver nitrate $\left(\mathrm{AgNO}_{3}\right)$ (Sambrook and Russel 2001) and visualized under white light. The molecular weight of the amplified fragments was assigned through comparison with a $1 \mathrm{~Kb}$ DNA ladder (Invitrogen Life Technologies).

The amplified fragments corresponding to putative differentially expressed transcripts were quantified by densitometry as Integrated Optical Density (IOD) using Imaging Master VDS Software version 3.2 (GE Healthcare Life Sciences). Mean and standard deviations (SD) were determined using the Microsoft Office Excel Software. The data were submitted to statistical analysis using Student's unpaired t-test $(\mathrm{p}<0.05)$ to normal distribution (Zar 1999). The previous selected fragments were reamplified in order to obtain a higher DNA content to be used on cloning and nucleotide sequencing. The fragments were cut from the polyacrylamide matrix and used directly on reamplification reactions, as described in Dakis and Kouretas (2002). Reamplification PCR conditions and primers were the same as described above. PCR products were cloned into pGEM-T (Promega) vector and used to transform competent cells of the E. coli strain DH5 $\alpha$ (Invitrogen Life Technologies), following the manufacturer's instructions. A total of 12 clones ( 6 clones of each selected fragment) were submitted to automated sequencing on an ABI 377 Automated DNA Sequencer (Applied Biosystems) with a DYEnamic ET Terminator Cycle Sequencing kit (GE Healthcare Life Sciences) following the manufacturer's instructions and using primers complementary to vector arms. Nucleic acid sequence database searches were performed using BLAST/N (Altschul et al. 1990) at the National Center for Biotechnology Information (NCBI) website (http://www.ncbi.nlm.nih.gov/blast). Sequence alignments were obtained by Clustal-W function (Thompson et al. 1994).

cDNA amplification using primer INS led to the identification of an intensely stained fragment of approximately 1,000 base pairs (bp), present in NT and in GH-transgenic zebrafish (Figure 1a), which seemed to correspond to a transcript with differential gene expression among different samples (Figure 1a). Densitometric analyses of this amplified product, through IOD values, evidenced a significant difference between transgenic and non-transgenic samples $(\mathrm{t}=0.0061)$, suggesting a lower gene expression level in the transgenic (104.02 \pm 57.71$)$ when compared to NT animals (249.75 \pm 30.08$)$ (Figure 2). 


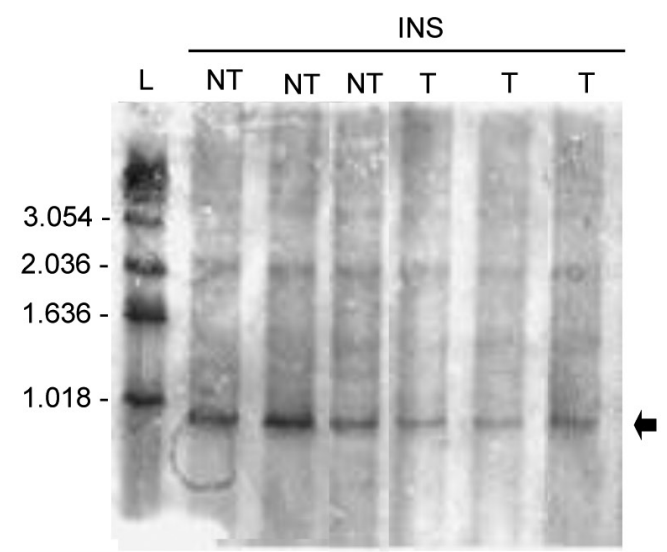

(a)

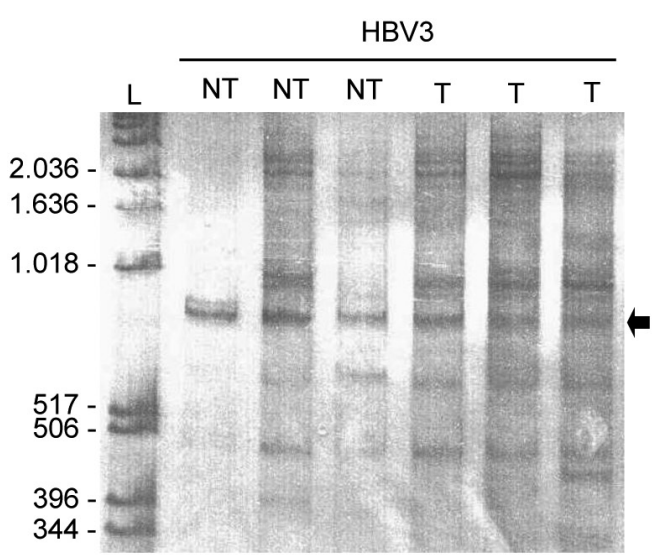

(b)

Figure 1: DDRT-PCR patterns of non-transgenic (NT) and GH-transgenic (T) zebrafish F0104 line, visualized trough 6\% polyacrilamide gel electrophoresis. (a) brain cDNA amplification using primer INS; (b) brain cDNA amplification using primer HBV3. L, $1 \mathrm{~Kb}$ DNA molecular marker. Arrows indicate putative differentially expressed transcripts between the samples.

Cloning and sequencing of this transcript permitted the characterization of a 941 bp DNA fragment. Database nucleotide searches indicated a $95 \%$ identity level with a partial region of the gene that codes for the p300 protein of Danio rerio (accession number XM_001332682, NM_001510744) and also a high identity with the p300 gene of several other vertebrates, as Ctenopharyngodon idella (81\%), Gallus gallus (81\%) and Mus musculus (78\%).

The use of the primer HBV3 to amplify the cDNA samples of Danio rerio resulted on several faint and diffuse bands (Figure 1b). However, a fragment of approximately $900 \mathrm{bp}$ was clearly visible in both NT and GH-transgenic samples (Figure 1b). The densitometric analyses of this transcript suggested a significant $(\mathrm{t}=0.0115)$ higher expression level in NT animals (342.95 \pm 65.19$)$ than in GH-transgenic fishes (224.10 \pm 91.73$)$ (Figure 2). Nucleotide sequencing analysis evidenced a DNA fragment with $831 \mathrm{bp}$, and BLAST database searches revealed a high identity level (94\%) with the 3' end of the gene that codes for the protein adenylate cyclase 2 (ADCY2) found in the brain tissue of Danio rerio (accession numbers CR759914 and GI6270118).
The p300, also known as E1A binding protein $\mathrm{p} 300$, is involved in several processes, as cellular differentiation and proliferation, cycle cell regulation, growth, apoptosis and histone acetylation (Huret 2000, Vleugel et al. 2006). Tan et al. (2009) suggested that this protein protects neuron from neurologic damages by inducing an increase of histone acetylation and preventing neuronal degeneration. Several studies have evidenced that the p300 is a transcriptional coactivator that interacts with other proteins, leading to the activation of the transcriptional process of several genes (Huret 2000, Tu and Luo 2007), including few genes related to cancer (Vleugel et al. 2006, Zhao et al. 2006, Chen et al. 2009) and neural pathologies development (Renoult et al. 2007, Francis et al. 2007). The relationship between $\mathrm{p} 300$ and $\mathrm{GH}$ was evidenced through an analysis of the $c$-fos proto oncogene expression - the GH activates the $c$-fos through a stimulation of the $\mathrm{p} 300$ protein, which acts as a transcription factor, to occupy the enhancer/ promoter region of the gene (Cui et al. 2005).

The Adenylate cyclase (AC) catalyses the conversion of ATP into cAMP, which, in turn, acts to regulate a wide variety of cellular processes. 


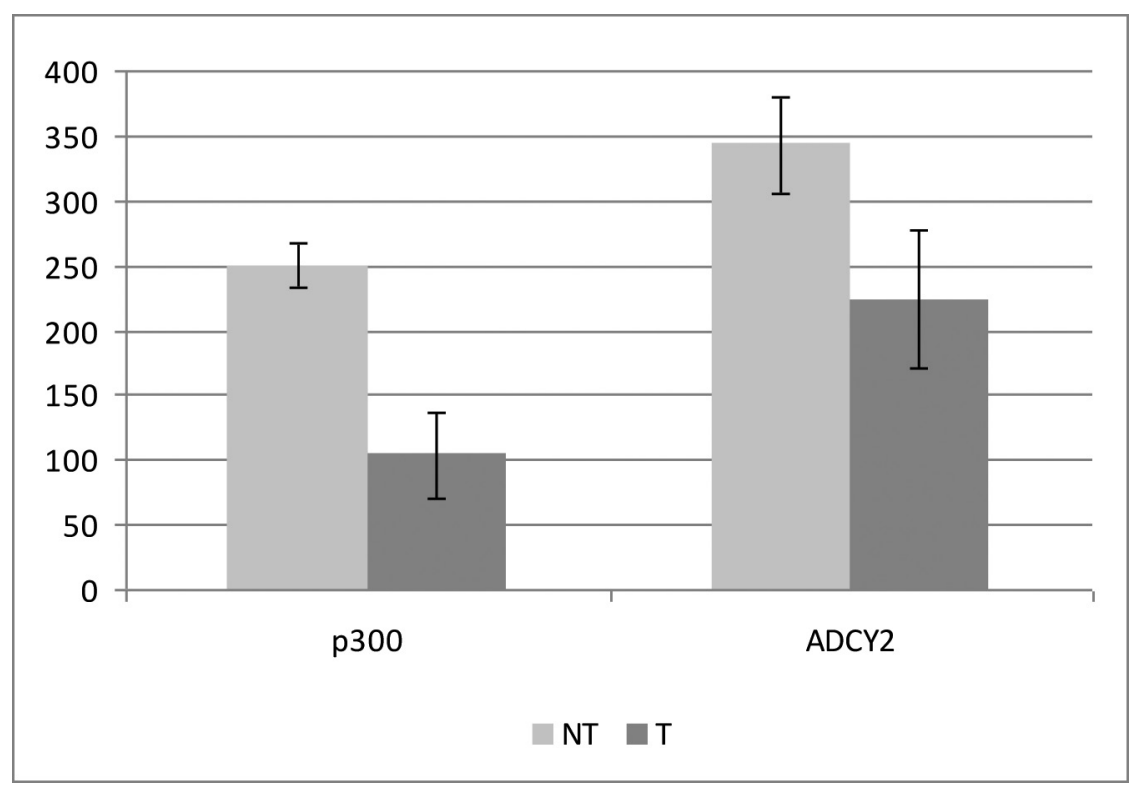

Figure 2: Densitometric analyses (Integrated Optical Density-IOD) of a fragment amplified with the primer INS that corresponds to the gene that codes for protein $\mathrm{p} 300$ (E1A binding protein p300) and of a fragment amplified with the primer HBV3 that corresponds to the gene that codes for protein ADCY2 (adenylate cyclase 2). These fragments correspond to putative differentially expressed transcripts identified through DDRT-PCR in non-transgenic (NT) and GH-transgenic (T) zebrafish F0104 line.

It was evidenced that the neuropeptide PACAP (pituitary adenylate cyclase-activating polypeptide) can modulate the AC activity, leading not only to the formation of cAMP, but also playing a role in mediating the growth hormone release in the pituitary gland of several vertebrates (Anderson et al. 2004, Mitchell et al. 2008), including some fishes as grass carp (Wong et al. 2005), common carp (Xiao et al. 2002), sockey salmon (Parker et al. 1997) and European eel (Montero et al. 1998). Likewise, increased concentrations of PACAP and/or higher concentrations of cAMP can effectively induce GH release (Anderson et al. 2004, Wong et al. 2005).

The present data indicate that the p300 and ADCY2 are involved in a regulation system for $\mathrm{GH}$ in zebrafishes in the presence of high circulating levels of this hormone. This study is the first step on the characterization of differentially expressed transcripts in brain tissues of GH transgenic and NT zebrafishes, and can lead to the development of new analyses related to the expression and regulation of these genes.

\section{ACKNOWLEDGMENTS}

This work was supported by grants from Fundação da Amparo à Pesquisa do Estado de São Paulo (FAPESP), Conselho Nacional de Desenvolvimento Científico e Tecnológico (CNPq), and Coordenação de Aperfeiçoamento de Pessoal de Nível Superior (CAPES).

\section{RESUMO}

A presença de níveis mais elevados do hormônio de crescimento $(\mathrm{GH})$ em animais transgênicos poderia levar a várias alterações fisiológicas. Uma linhagem transgênica de paulistinha (Danio rerio) para o GH foi comparada com amostras não transgênicas (NT) desta espécie, através de uma abordagem de DDRT-PCR, com o objetivo de identificar transcritos candidatos diferencialmente expressos em tecido cerebral que poderiam estar envolvidos na superexpressão de GH. Análises densitométricas de dois produtos de amplificação selecionados, p300 e $A D C Y 2$, apontaram uma expressão gênica significativamente menor nas amostras transgênicas de paulistinha (104.02 \pm 57.71 ; 224.10 \pm 91.73 ), quando comparadas com as amostras 
NT (249.75 $\pm 30.08 ; 342.95 \pm 65.19)$. Os presentes dados indicam que p300 e ADCY2 estão envolvidos em um sistema de regulação do $\mathrm{GH}$, quando altos níveis circulantes desse hormônio são encontrados em paulistinha.

Palavras-chave: display diferencial, GH, hormônio de crescimento, transgênico, paulistinha.

\section{REFERENCES}

Altschul SF, Gish W, Miller W, Myers EW AND Lipman DJ. 1990. Basic local alignment search tool. J Mol Biol 215: 403-410.

ANDERSON LL, JefTiniJa S AND Collin SG. 2004. Growth hormone secretion: molecular and cellular mechanisms and in vivo approaches. Exp Biol Med 229: 291-302.

BARTKE A, BROWN-BORG HM, BODE AM, CARLSON J, HUNTER WS AND BRONSON RT. 1998. Does growth hormone prevent or accelerate aging? Exp Gerontol 33: 675-687.

Bohlooly-y M, Bollano E, Mobini R, SOussi B, TORnell J AND OMEROVIC E. 2005. Selective cerebral overexpression of growth hormone alters cardiac function, morphology, energy metabolism and catcholamines in transgenic mice. Growth Horm IGF Res 15: 148-155.

BROWN-BORG H, JOHNSON WT, RAKOCZY S AND ROMANICK M. 2001. Mitochondrial oxidant generation and oxidative damage in ames dwarf and GH transgenic mice. J Am Aging Assoc 24: 85-100.

Chen YL, Lin G, HuO JS, BARNEY D, WANG ZN, LiYSHIZ T, STATES DJ, QIN ZHS AND SChwARTZ J. 2009. Computational and functional analysis of growth hormone $(\mathrm{GH})$ regulated genes indentifies the transcriptional repressor B-cell lymphoma 6 (Bs16) as a participant in GH-regulated transcription. Endocrinology 150: 3645-3654.

COOK JT, MCNIVEN MA AND SuTTERLIN AM. 2000. Metabolic rate of pre-smolt growth-enhanced transgenic Atlantic salmon (Salmo salar). Aquaculture 188: 33-45.

CUI TX, PiwiEn-PilipuK G, HuO JS, KaPlani J, KwOK R AND SCHWARTZ J. 2005. Endogenous CCAAT/enhancer binding protein $\beta$ and $\mathrm{p} 300$ are both regulated by growth hormone to mediate transcriptional activation. Mol Endocrinol 19: 2175-2186.

DAKIS D AND KOURETAS D. 2002. Differential display of m-RNAs in fish gonads by modified DD-PCR. In Vivo 16: 103-105.

DEVLIN RH, BIAGI CA, YeSAKI TY, SMAILUS DE AND BYATT JC. 2001. Growth of domesticated transgenic fish. Nature 409: 781-782.

FigueIREDO MA, LANES CFC, ALMEIDA DV AND MARINS LF. 2007. Improving to production of transgenic fish germlines: In vivo evaluation of mosaicism in zebrafish (Danio rerio) using a green fluorescent protein (GFP) and growth hormone cDNA transgene co-injection strategy. Genet Mol Biol 30: 31-36.
FRANCIS YI, DISS JKJ, KARITI M, STEPHANOU A AND LATCHMAN DS. 2007. p300 activation by presenilin 1 but not by its M146L mutant. Neurosci Lett 413: 137-140.

HARRIS AS AND WRIGTH JM. 1995. Nucleotide sequence and genomic organization of cichlid fish minisatellites. Genome 38: 177-184.

HURET JL. 2000. EP300 (E1A binding protein p300). The Atlas of Genetics and Cytogenetics in Oncology and Haematology, accessible at http://AtlasGeneticsOncology. org. (Accessed 16/08/2009).

IKEDA A, CHANG K, Matsumoto Y, FURUHATA Y, NishiHaRA M, SASAKI F AND TAKAHASHI M. 1998. Obesity and insulin resistance in human growth hormone transgenic rats. Endocrinology 139: 3057-3063.

Lall S, Balthasar N, Carmignac D, Magoulas C, Sesay A, Houston P, MATHERS K AND RobINSON I. 2004. Physiological studies of transgenic mice overexpressing growth hormone $(\mathrm{GH})$ secretagogue receptor $1 \mathrm{~A}$ in $\mathrm{GH}-$ releasing hormone neurons. Endocrinology 145: 1602-1611.

LIANG P. 2002. A decade of differential display. Bio Techniques 33: $338-346$

Mitchell G, SAWISKy GR, GRey CL, Wong CJ, URETSKY AD AND CHANG JP. 2008. Differential involvement of nitric oxide signalling in dopamine and PACAP stimulation of growth hormone release in goldfish. Gen Comp Endocrinol 155: 318-327.

Montero M, Yon L, Rousseau K, Arimura A, Fournier A, DUFOUR S AND VAUDRY H. 1998. Distribution, characterization, and growth hormone-releasing activity of pituitary adenylate cyclase - activing polypeptide in the European eel (Anguilla anguilla). Endocrinology 139: 4300-4310.

MÜller EE, LOCATELli V AND COCCHI D. 1991. Neuroendocrine control of growth hormone secretion. Physiol Rev 79: 511-607.

Murray MJ, Haldeman BA, Grant FJ ANd O'Hara N. 1988. Probing the human genome with minisatellite-like sequences from the human coagulation factor-VII gene. Nucleic Acids Res 16: 4166

NAKAMURA Y ET AL. 1987. Variable number of tandem repeat (VNTR) markers for human-gene mapping. Science 235: 1616-1622.

PARDEE AB AND MCCLELLAND M. 1999. Expression genetics: differential display. IN: PARDEE AB AND MC CLELLAND M (Eds), Expression genetics: differential display, Eaton Publishing, USA, p. 1-7.

PARKER DB, POWER ME, SWANSON P, RIVIER J AND SHERWOOD NM. 1997. Exon skipping in the gene encoding pituitary adenylate cyclase-activating polypeptide in salmon alters the expression of two hormones that stimulate growth hormone release. Endocrinology 138: 414-423.

Renoult L, Prevost M, Brodeur M, Lionnet C, Joober R, Malla A AND Debruille JB. 2007. P300 asymmetry and positive symptom severity: A study in the early stage of a first episode of psychosis. Schizophr Res 93: 366-373. 
Rosa CE, Figueiredo MA, LAnes CFC, Almeida DV, MONSERRAT JM AND MARINS LF. 2008. Metabolic rate and reactive oxygen species productions in different genotypes of GH-transgenic zebrafish. Comp Biochem Physiol B 149: 209-214.

SAMBROOK J AND RUSSEL DW. 2001. Molecular cloning. A Laboratory Manual, $3^{\text {rd }}$ ed., New York: Cold Spring Harbor Laboratory Press.

TAN XL, ZHAI Y, GAO WX, FAN YM, LIU FY, HUANG QY AND GAO YQ. 2009. p300 expression is induced by oxygen deficiency and protects neuron cells from damage. Brain Res 1254: 1-9.

Thompson JD, HigGINs DG AND GiBson TJ. 1994. Clustal W: improving the sensitivity of progressive multiple sequence alignment through sequence weighting, position-specific gap penalties and weight matrix choice. Nucleic Acids Res 22: 4673-4680.

Tu AW AND LUO K. 2007. Acetylation of Smad2 by the coactivator p300 regulates activin and TGF $\beta$ response. J Biol Chem 282: 21187-21196.

Vleugel MM, ShVARTs D, WALl E AND Diest PJ. 2006. p300 and p53 levels determine activation of HIF-1 downstream targets in invasive breast cancer. Hum Pathol 37: 1085-1092.
Wong AO, Li W, Leung CY, HuO L ANd ZhOU H. 2005. Pituitary adenylate cyclase-activating polypeptide (PACAP) as a growth hormone (GH)-releasing factor in grass carp. I. Functional coupling of cyclic adenosine 3',5'-monophosphate and $\mathrm{Ca} 2+/$ calmodulin-dependent signalling pathways in PACAP-induced GH secretion and GH gene expression in grass carp pituitary cells. Endocrinology 146: 5407-5424.

Xiao D, Chu MMS, LeE EKY, Lin H-R And Wong AOL. 2002. Regulation of growth hormone release in common carp pituitary cells by pituitary adenylate cyclaseactivating polypeptide: signal transduction involves cAMP and calcium-dependent mechanisms. Neuroendocrinology 76: 325-338.

ZAR JH. 1999. Biostatistical analysis, New Jersey: PrenticeHall, 663 p.

Zhao L-J, Subramanian T AND Chinnadurai G. 2006. Changes in C-terminal binding protein 2 (CtBP2) corepressor complex induced by E1A and modulation of E1A transcriptional activity by CtBP2. J Biol Chem 281: 36613-36623. 